\title{
BIPOLINIO SUTRIKIMO VALDYMAS NËŠTUMO IR POGIMDYMINIU LAIKOTARPIU
}

\author{
Rasa Saulytė ${ }^{1}$ Ieva Zarinskaitė ${ }^{1}$, Alma Griškevičiūtėe \\ ${ }^{1}$ Lietuvos sveikatos mokslu universiteto Medicinos akademijos Medicinos fakultetas, \\ ${ }^{2}$ Lietuvos sveikatos mokslu universiteto Kauno ligonine, Psichiatrijos klinika
}

Raktažodžiai: bipolinis sutrikimas, nėštumas, psichikos sveikata, žindymas.

\begin{abstract}
Santrauka
Bipolinis sutrikimas (BS) - tai nuolatinis afektinis nuotaikos sutrikimas, pasižymintis pasikartojančiais nuotaikos ir aktyvumo lygio pakitimo epizodais. Moterys ir vyrai BS serga vienodai dažnai (apie $1 \%$ populiacijos). BS etiologiją apima paveldimumas, aplinkos veiksniai, traumos bei hormoniniai sutrikimai.

Bipolinio sutrikimo gydymas nëštumo laikotarpiu turètų atitikti naujausias gaires. BS valdymas turètų apimti rizikos vertinimą ir mažinimą, farmakoterapiją, šviesos terapiją ir psichoterapiją. Elektrokonvulsinè terapija turètu būti taikoma tik išimtiniais atvejais, ịvertinus naudos bei žalos santykị motinai ir vaisiui.
\end{abstract}

\section{Ivadas}

Bipolinis sutrikimas yra psichikos sutrikimas, susijęs su nuotaikos svyravimais, kurie pasireiškia nuotaikos pablogèjimo (depresijos) ir nuotaikos pakilimo periodais (hipomanijos arba manijos). Manijos epizodo metu pasireiškia pakili nuotaika ir linksmumas, padidejja energija bei aktyvumas. Depresijos epizodo metu energija bei interesai sumažeja, vargina liūdna nuotaika, jègų nebuvimas, sutrikusi dèmesio koncentracija [1]. BS moterims dažniausiai diagnozuojamas nuo 18 iki 30 metų - tai sutampa su laikotarpiu, kai daugelis moterų pradeda planuoti néštumą [2]. Perinataliniu laikotarpiu moterys, sergančios bipoliniu sutrikimu, yra pažeidžiamos dèl depresijos epizodų pasikartojimo, jų didesnè rizika susirgti pogimdyvine psichoze, todèl ypač svarbu tinkamai prižiūrèti besilaukiančias moteris, nes BS atkryčio rizika po gimdymo yra labai didelè, siekia $30-90$ procentų [3].

Tyrimo tikslas - atlikti 2015 - 2021 metais išspausdintų mokslinių šaltinių, nagrinėjančių bipolinio sutrikimo něštumo laikotarpiu klinikinę reikšmę, sisteminę analizę ir apibendrinti jo valdymą.

\section{Tyrimo medžiaga ir metodai}

Atlikta mokslinès literatūros apžvalga. Duomenys rinkti iš kompiuterinių bibliografinių medicininių duomenų bazių PubMed, ScienceDirect, Medscape ir UpToDate. Paieška buvo vykdoma naudojant reikšminius žodžius: bipolar disorder, mental health, pregnancy, breastfeeding.

Apžvalgai naudoti 2015-2021 metais spausdinti straipsniai anglų kalba, atitinkantys tyrimo temą.

\section{Tyrimo rezultatai}

Klinika. Bipoliniam sutrikimui būdingi manijos, hipomanijos ir sunkios depresijos epizodai. BS gali būti I, II ar mišraus tipo [4]. Pacientès, turinčios I tipo bipolinį sutrikimą, patiria bent vieną manijos ar mišrios būsenos epizodą, po kurio dažniausiai seka ilgas depresijos epizodas. II tipo bipolinis sutrikimas pasižymi bent vienu ryškiu depresijos epizodu, po kurio seka hipomanijos (bet ne manijos) epizodas [5].

Su nėštumu susijusi rizika. BS gali sukelti įvairių pavojingų būklių něštumo metu. Šis sutrikimas daro didelę itaką pacientės psichinei ir fizinei sveikatai, profesinei veiklai bei tarpasmeniniams santykiams, todèl būtina aptarti galimas rizikas su besilaukiančiomis moterimis bei jų artimaisiais, kurie galètų psichologiškai palaikyti pacientę néštumo metu ir po jo [6].

Recidyvas néštumo metu. Pacientès, sergančios BS, nèštumo metu dažnai patiria nuotaikos epizodus, tačiau nèra žinoma, ar nëštumas keičia jų pasikartojimo riziką. Kai kurioms moterims néštumo metu BS epizodų gali būti mažiau, o kitų něščiujų ligos eiga išlieka nepakitusi arba pablogejja [7]. Sergančių BS néščiujų stebėjimo tyrimai parodè šiuos pasikartojimo dažnius: dviejuose perspektyviniuose tyrimuose nustatyta, kad bent vienas nuotaikos epizodas něštumo metu ịvyko daugiau nei 70 proc. pacienčių; atlikus trečiajji tyrimą, nuotaikos epizodai nustatyti 24 proc. pacienčių. Prospektyvinis stebejjimo tyrimas, kuriame dalyvavo 63 nèščiosios, patyrusios nuotaikos epizodą, parodè, kad 66,6 proc. 
pacienčiu ji patyre pirmaji trimestrą, 23,8 proc. - antrajị ir 9,5 proc. - trečiajji. Dažniausias nėščiujjų nuotaikos epizodas yra sunki depresija (42\%), mišrus: depresijos ir manijos (hipomanijos) simptomai (32\%), manija ar hipomanija (26\%). Klinikiniai veiksniai, kurie gali būti susiję su ligos recidyvu neštumo metu, yra trumpesnis klinikinio stabilumo laikotarpis iki pastojimo, farmakoterapijos nutraukimas, neplanuotas nèštumas bei gretutinis psichiatrinis susirgimas [8].

Recidyvas, nutraukus farmakoterapija. Reguliarus vaistų vartojimas něštumo metu apsaugo sergančiąsias BS nuo nuotaikos epizodų kartojimosi. Atliktas perspektyvinis stebejjimo tyrimas parodé, jog recidyvas rečiau pasireiškè toms něščiosioms, kurios tęsė farmakoterapiją nèštumo metu, nei toms, kurios vaistų vartojimą nutraukè. Nuotaikos epizodų pasikartojimo rizika besilaukiančioms pacientėms yra didesnè, jei gydymas nutraukiamas staiga [9].

Nuotaikos epizodai po gimdymo. Atliktas 1120 pacienčių, sergančių BS, retrospektyvinis tyrimas parode, jog nuotaikos epizodai pogimdyviniu laikotarpiu (šešis mènesius po gimdymo) įvyko du kartus dažniau, nei néštumo metu.

Igimti vaisiaus defektai. BS sergančių pacienčių vaisiaus igimtų defektų dažnis nesiskiria nuo bendros populiacijos (2-5\%), tačiau, kai kurie vaistai, vartojami BS gydyti, yra teratogeniški (valproatas, litis, karbamazepinas) $[10,11]$.

Nëštumo komplikacijų rizika. Nepageidaujami néštumo bei gimdymo rezultatai dažniau pasireiškia moterims, sergančioms BS. Atliktame tyrime buvo lyginamos sveikų néščiųų, sergančių BS ir gydytų vaistais, sergančių BS ir negydytų vaistais gimdymo baigtys. Rezultatai parodè, jog planinė ar spontaniné cezario pjūvio operacija buvo dažniau taikyta BS sergančioms pacientėms. Priešlaikinis gimdymas buvo dažnesnis ir gydytoms, ir negydytoms BS sergančioms moterims [5].

Psichopatologijos paveldejjimas vaisiui. Psichikos ligų išsivystymui didelę reikšmę turi paveldimumas [12]. Atliktas tyrimas palygino šizofrenijos ir BS paveldimumą pirmos kartos palikuonims. Šizofrenijos paveldimumas buvo 64 proc., o bipolinio sutrikimo - 59 proc., jei serga abu tévai. Jei serga vienas iš tèvų, BS paveldimumo tikimybė siekia 20-25 procentus [13].

Nèštumo rizikos mažinimas. Moterims, sergančioms BS ir norinčioms pastoti, siūloma palaukti, kol būklè taps kliniškai stabili, mažiausiai $6-24$ mėnesius. Perspektyvinis stebejjimo tyrimas parodè, kad trumpas klinikinio stabilumo laikotarpis buvo susijęs su nuotaikos epizodų pasikartojimu nėštumo metu. Siekiant išvengti nervinio vamzdelio defektų, moterims rekomenduojama vartoti folio rūgštị vieną mėnesị prieš pastojimą ir 2-3 ménesius po apvaisinimo [14,15].

BS valdymo principai. Farmakoterapija yra pagrindinis bipolinio sutrikimo gydymo būdas, o vaistų vartojimo nauda nèštumo ir žindymo laikotarpiu dažiausiai pateisina riziką. Nepakankamai gydomas BS nëštumo metu yra susijęs su blogesniais gimdymo rezultatais, įskaitant priešlaikinị gimdymą, mažą gimimo svorį, vaisiaus augimo sulètejimą ar vaisiaus distresą [16].

Medikamentinis gydymas. Litis bei vaistai nuo epilepsijos skiriami ilgalaikiam palaikomajam gydymui, siekiant užkirsti kelią depresijos bei manijos epizodams [17]. Antrosios kartos antipsichotikai, taip pat skiriami palaikomajam gydymui, yra veiksminga ūmios manijos epizodų gydymo priemonè. Nors valproine rūgštis yra veiksmingas nuotaikos stabilizatorius, vaisingo amžiaus moterims ir něščiosioms pirmenybė teikiama kitiems vaistams, mažinant kūdikio apsigimimų ir vystymosi anomalijų riziką [18].

Litis. Ličio poveikis vaisiui susijęs su širdies anomalijų rizika, laikina naujagimių hipotiroze, tachikardija, tačiau raidos sutrikimų nestebima. Nëščiajai turi būti skiriama mažiausia efektyvi dozè, du kartus per parą, siekiant išvengti didelès ličio koncentracijos serume $(<600 \mathrm{mg})$ [19]. Moterims, kurios pagimdè išnešiotus naujagimius, siūloma maitini krūtimi, stebèti dèl galimo kūdikio neramumo, elgesio pakitimų ar padidejusios sedacijos [20].

Lamotriginas (LTG). Igimtų apsigimimų rizika vartojant LTG nenustatyta. Nors Šiaurès Amerikos registras praneša apie padidejjusi vaisiaus gomurio plyšimo pavojų, LTG išlieka vienu optimaliausių pasirinkimų, gydant BS [21]. LTG yra saugus vaistas besilaukiančioms ir žindančioms moterims, itin retai sukeliantis nepageidaujamų reakcijų [22]. Žindomų kūdikių kraujo mėginiuose LTG koncentracija buvo žymiai mažesnè, negu motinos kraujyje. Tai rodo, jog motinai vartojant vaistus nuo epilepsijos, reikšmingo neigiamo poveikio vaisiui nèra [23].

Karbamazepinas. Karbamazepino vartojimas nèštumo metu susijęs su ịgimtų apsigimimų padaugejjimu. Atliktas perspektyvinis tyrimas ir metaanalize parodè, jog karbamazepino monoterapija reikšmingai susijusi su nervinio vamzdelio, širdies ir šlapimo takų defektais, nagų hipoplazija, vystymosi vélavimu bei kaukolès deformacijomis [24]. Nustatyta, kad karbamazepiną galima vartoti maitinant krūtimi. Jei motinai reikalingas karbamazepinas, tai nėra priežastis nutraukti žindymą, tačiau reiktų susirūpinti, jei naujagimis taptų mieguistesnis, vangesnis ar sutriktų čiulpimo refleksas [25].

Antrosios kartos antipsichoziniai vaistai, išskyrus risperidoną, nèra susiję su padidejusia ịgimtų apsigimimų rizika. Buvo nustatyta, jog nutukusioms besilaukiančioms moterims vartojant antipsichozinius vaistus (olanzapiną, kvetiapiną), smarkiai padideja gestacinio diabeto bei preeklampsijos rizika, o vaisiui makrosomijos, priešlaikinio gimimo, polihidramniono bei gimdymo traumos rizika [26]. Olanzapinas didžiajai moterų daliai (82,3\%) NR žindymo 
metu nesukèlè, o sukeltos retos NR buvo mieguistumas $(3,9 \%)$, dirglumas (2\%), drebulys (2\%) ir nemiga (2\%) [27].

Nemedikamentinis gydymas. Šviesos terapija (ŠT). Ryškios šviesos terapija yra patvirtintas depresijos simptomų gydymo būdas, kurị apima plataus spektro šviesos poveikis. ŠT veiksmingiausia yra tada, kai gydymas derinamas kartu su nuotaikos stabilizatoriumi. Šią terapiją geriausia taikyti vidurdieni, pradedant nuo $15 \mathrm{~min}$. per dieną pirmają savaitę, laipsniškai didinant dozę [28]. ŠT nèra susijusi su jokia reprodukcine rizika, šviesos taikymas nëštumo metu yra saugus, tačiau ją taikyti draudžiama manijos, hipomanijos ar mišrios nuotaikos epizodų metu. Šalutinis ŠT poveikis yra galvos skausmas, pykinimas ir nervingumas [29].

Psichoterapija. BS gali būti sèkmingai stabilizuojamas psichoterapijos pagalba, jei paciente yra motyvuota, bendradarbiaujanti bei laikosi gydytojo rekomendacijų. Dažniausiai taikoma kognityvinè elgesio terapija (KET), tarpasmeniné psichoterapija bei porų terapija [30]. Sisteminè randomizuotų klinikinių tyrimų metaanalizè parodè, jog KET veiksmingai mažina BS atkryčio dažnį, depresijos simptomus bei manijos epizodų pasireiškimą. Reikšmingas teigiamas poveikis pasireiškia, kai KET vieno seanso gydymo trukmè yra $\geq 90$ minučių [31].

Gydymui rezistentiškas BS. Elektrokonvulsinè terapija (EKT) yra efektyvi ir veiksminga elektros srovių praleidimo per smegenis procedūra, siekiant sumažinti sunkius psichinès sveikatos simptomus. Tai veiksminga galimybè pacientėms, sergančioms gydymui atspariu BS, kurioms pasireiškia sunkūs nuotaikos epizodai, padidintas polinkis ị savižudybę ar psichozė [32], tačiau atliktas tyrimas net trečdaliui besilaukiančiujų nustatė nepageidaujamus reiškinius: vaisiaus širdies susitraukimų dažnio sumažejimą, retesnius gimdos susitraukimus ir priešlaikinị gimdymą (nuo 29 iki 37 nèštumo savaitès). Bendras naujagimių mirtingumas buvo 7,1 procento. Nëštumo metu EKT rekomenduojama taikyti tik kraštutiniu atveju, taikant labai griežtas diagnostines ir klinikines indikacijas [33].

\section{Išvados}

1. Negydomas BS néštumo metu susijęs su blogesniais gimdymo rezultatais, ịskaitant priešlaikinị gimdymą, mažą gimimo svorị, vaisiaus augimo sulètējimą ar vaisiaus distresą.

2. Pacientèms, nèštumo metu vartojančioms liț ar lamotriginą, rekomenduojama nuolat stebèti terapinị ir nepageidaujamą poveikį, o esant indikacijai - koreguoti dozę.

3. Šviesos terapija yra saugi ir veiksminga nemedikamentinè priemonė gydant BS depresijos epizodus nėštumo ir pogimdyminiu laikotarpiais.

4. Elektrokonvulsinę terapiją nëštumo metu rekomenduojama taikyti tik išimtiniu atveju, taikant labai griežtas diagnostines ir klinikines indikacijas.

\section{Literatūra}

1. Barahona-Correa B, Ribeiro R. The neuroanatomy of secondary bipolar disorder. Journal of Neurology Neurosurgery \& Psychiatry 2015;86(9).

https://doi.org/10.1136/jnnp-2015-311750.53

2. McCormick U, Murray B, McNew B. Diagnosis and treatment of patients with bipolar disorder. J Am Assoc Nurse Pract 2015; 27(9): 530-542.

https://doi.org/10.1002/2327-6924.12275

3. Bergink V, Burgerhout KM, Koorengevel K, et al. Treatment of psychosis and mania in the postpartum period. Am J Psychiatry 2015;172(2):115-23.

https://doi.org/10.1176/appi.ajp.2014.13121652

4. Clemente AS, Diniz BS, Nicolato R, et al. Bipolar disorder prevalence: a systematic review and meta-analysis of the literature. Braz J Psychiatry 2015;37(2):155-61.

5. Hendrick V. Bipolar disorder in women: contraception and preconception assessment and counselling. In: UpToDate, Keck, P (Ed), UpToDate 2021.

https://doi.org/10.1590/1516-4446-2012-1693

6. Carlborg A, Ferntoft L, Thuresson M, et al. Population study of disease burden, management, and treatment of bipolar disorder in Sweden: a retrospective observational registry study. Bipolar Disord 2015;17(1):76-85.

https://doi.org/10.1111/bdi.12234

7. Kameg BN. Bipolar disorder: treatment strategies for women of childbearing age. Perspect Psychiatr Care 2020.

https://doi.org/10.1111/ppc.12680

8. Wesseloo R, Kamperman AM, Munk-Olsen T, et al. Risk of postpartum relapse in bipolar disorder and postpartum psychosis: a systematic review and meta-analysis. Am J Psychiatry 2016;173(2):117-27.

https://doi.org/10.1176/appi.ajp.2015.15010124

9. Jones I, Chandra PS, Dazzan P, et al. Bipolar disorder, affective psychosis, and schizophrenia in pregnancy and the post-partum period. Lancet 2014;384(9956):1789-99.

https://doi.org/10.1016/S0140-6736(14)61278-2

10. Zhang L, Li H, Li S, et al. Reproductive and metabolic abnormalities in women taking valproate for bipolar disorder: a metaanalysis. Eur J Obstet Gynecol Reprod Biol 2016 ;202:26-31. https://doi.org/10.1016/j.ejogrb.2016.04.038

11. Mei-Dan E, Ray JG, Vigod SN. Perinatal outcomes among women with bipolar disorder: a population-based cohort study. Am J Obstet Gynecol 2015;212(3):367.e1-8. https://doi.org/10.1016/j.ajog.2014.10.020

12. Inglis A, Morris E, Austin J. Prenatal genetic counselling for psychiatric disorders. Prenat Diagn 2017;37(1):6. https://doi.org/10.1002/pd.4878

13. Lichtenstein P, Yip BH, Björk C, et al. Common genetic determinants of schizophrenia and bipolar disorder in Swedish fami- 
lies: a population-based study. Lancet 2009;373(9659):234-9. https://doi.org/10.1016/S0140-6736(09)60072-6

14. Garner ChD. Nutrition in pregnancy. In: UpToDate, Lockwood, ChJ (Ed), UpToDate 2021.

15. Chitayat D, Matsui D, Amitai Y, et al. Folic acid supplementation for pregnant women and those planning pregnancy: 2015 update. J Clin Pharmacol 2016;56(2):170-5.

https://doi.org/10.1002/jcph.616

16. Rusner M, Berg M, Begley C. Bipolar disorder in pregnancy and childbirth: a systematic review of outcomes. BMC Pregnancy Childbirth 2016;16(1):331. https://doi.org/10.1186/s12884-016-1127-1

17. Jones SC, Jones I. Pharmacological management of bipolar disorder in pregnancy. CNS Drugs 2017;31(9):737-745. https://doi.org/10.1007/s40263-017-0452-x

18. Fornaro M, Maritan E, Ferranti R, et al. Lithium exposure during pregnancy and the postpartum period: a systematic review and meta-analysis of safety and efficacy outcomes. Am J Psychiatry 2020;177(1):76-92. https://doi.org/10.1176/appi.ajp.2019.19030228

19. Poels EMP, Bijma HH, Galbally M, et al. Lithium during pregnancy and after delivery: a review. Int J Bipolar Disord 2018;6(1):26.

https://doi.org/10.1186/s40345-018-0135-7

20. Imaz ML, Torra M, Soy D, et al. Clinical lactation studies of lithium: a systematic review. Front Pharmacol 2019;10:1005. https://doi.org/10.3389/fphar.2019.01005

21. Prakash, Prabhu LV, Nasar MA, et al. Lamotrigine in pregnancy: safety profile and the risk of malformations. Singapore Med J 2007;48(10):880-3.

22. Dalili H, Nayeri F, Shariat M, et al. Lamotrigine effects on breastfed infants. Acta Med Iran 2015;53(7):393-4.

23. Birnbaum AK, Meador KJ, Karanam A, et al. Antiepileptic drug exposure in infants of breastfeeding mothers with epilepsy. JAMA Neurol 2020;77(4):441-450.

https://doi.org/10.1001/jamaneurol.2019.4443

24. Jentink J, Dolk H, Loane MA, et al. Intrauterine exposure to carbamazepine and specific congenital malformations: systematic review and case-control study. BMJ 2010;341:c6581. https://doi.org/10.1136/bmj.c6581

25. Drugs and Lactation Database (LactMed). Bethesda (MD): National Library of Medicine (US); 2006-. Carbamazepine 2021.

26. Betcher HK, Wisner KL. Psychotropic treatment during pregnancy: research synthesis and clinical care principles. J Womens Health (Larchmt) 2020;29(3):310-318.

https://doi.org/10.1089/jwh.2019.7781

27. Brunner E, Falk DM, Jones M, et al. Olanzapine in pregnancy and breastfeeding: a review of data from global safety surveil- lance. BMC Pharmacol Toxicol 2013;14:38.

https://doi.org/10.1186/2050-6511-14-38

28. Deligiannidis KM, Freeman MP. Complementary and alternative medicine therapies for perinatal depression. Best Pract Res Clin Obstet Gynaecol 2014; 28(1):85-95.

https://doi.org/10.1016/j.bpobgyn.2013.08.007

29. Bais B, Kamperman AM, Bijma HH, et al. Effects of bright light therapy for depression during pregnancy: a randomised, double-blind controlled trial. BMJ Open $2020 ; 10(10)$ :e038030. https://doi.org/10.1136/bmjopen-2020-038030

30. Grande I, Berk M, Birmaher B, et al. Bipolar disorder. Lancet $2016 ; 387(10027): 1561-1572$. https://doi.org/10.1016/S0140-6736(15)00241-X

31. Chiang KJ, Tsai JC, Liu D, et al. Efficacy of cognitive-behavioral therapy in patients with bipolar disorder: a metaanalysis of randomized controlled trials. PLoS One 2017; 12(5): 0176849.

https://doi.org/10.1371/journal.pone.0176849

32. Thyen A, Narang P, Sarai S, et al. Electroconvulsive therapy during pregnancy. Prim Care Companion CNS Disord 2017;19(4):17br02096.

https://doi.org/10.4088/PCC.17br02096

33. Leiknes KA, Cooke MJ, Jarosch-von Schweder L, et al. Electroconvulsive therapy during pregnancy: a systematic review of case studies. Arch Womens Ment Health 2015;18(1):1-39. https://doi.org/10.1007/s00737-013-0389-0

\section{MANAGEMENT OF BIPOLAR DISORDER DURING PREGNANCY AND THE POSTPARTUM PERIOD \\ R. Saulytė, I. Zarinskaitė, A. Griškevičiūtė}

Keywords: bipolar disorder, mental health, pregnancy, breastfeeding.

Summary

Bipolar affective disorder (BD) is a common, severe, and persistent mental illness, characterised by regularly recurring episodes of notable changes in affect. Bipolar disorder is equally common in women and men (about $1 \%$ of the population). The etiology of BD includes heredity, environmental factors, trauma, and hormonal disorders. Treatment of BD during pregnancy should follow the latest guidelines. Management of BD should include risk assessment and mitigation, pharmacotherapy, light therapy and psychotherapy. Electroconvulsive therapy should be used only in exceptional cases, after assessing the benefit-risk balance for the mother and fetus.

Correspondence to: rassa.saulyte@gmail.com

Gauta 2021-04-13 